\title{
Review \\ The role of androgens and polymorphisms in the androgen receptor in the epidemiology of breast cancer
}

\author{
Elizabeth O Lillie ${ }^{1}$, Leslie Bernstein ${ }^{1}$ and Giske Ursin ${ }^{1,2}$
}

\author{
1'Department of Preventive Medicine, Keck School of Medicine, University of Southern California, Los Angeles, California, USA \\ ${ }^{2}$ Currently at Insitution for Nutrition Research, University of Oslo, Norway \\ Corresponding author: Elizabeth O Lillie (e-mail: osth@usc.edu)
}

Published: 2 April 2003

Breast Cancer Res 2003, 5:164-173 (DOI 10.1186/bcr593)

(c) 2003 BioMed Central Ltd (Print ISSN 1465-5411; Online ISSN 1465-542X)

\begin{abstract}
Testosterone binds to the androgen receptor in target tissue to mediate its effects. Variations in testosterone levels and androgen receptor activity may play a role in the etiology of breast cancer. Here, we review the epidemiologic evidence linking endogenous testosterone to breast cancer risk. Paradoxically, results from observational studies that have examined polymorphisms in the androgen receptor suggest that the low-activity androgen receptor increases breast cancer risk. We review the quality of this evidence and conclude with a discussion of how the androgen receptor and testosterone results coincide.
\end{abstract}

Keywords: androgen receptor, breast cancer, CAG polymorphism, testosterone

\section{Introduction}

The role of androgens in breast cancer etiology has been a subject of both curiosity and confusion. It is still unclear by which mechanisms testosterone exerts its activity in the female breast, and whether the effects are predominantly proliferative or anti-proliferative on breast cells at physiologic levels. In the present review we evaluate the results from epidemiologic studies on the role of circulating testosterone and a functional polymorphism in the androgen receptor (AR) in breast cancer. We also highlight some of the epidemiologic challenges in addressing these questions.

\section{Sources of endogenous testosterone}

There are two main sources of androgens in women. Testosterone is produced directly by the ovary and by conversion of the adrenal androgens dehydroepiandrosterone and dehydroepiandrosterone-sulfate into androstenedione, and then further to testosterone in peripheral tissue [1]. In premenopausal women, approximately $25 \%$ of circulating testosterone is secreted directly from the adrenal gland and 25\% from the ovary, whereas the remaining $50 \%$ is produced by peripheral conversion of androstenedione [2]. Testosterone levels vary over the menstrual cycle with peak levels mid-cycle, and diurnally with highest levels in the early morning [3].

Testosterone and androstenedione are produced by the interstitial cells of the ovarian stroma and may continue to respond to gonadotopins and produce testosterone after the menopause [4]. In normal postmenopausal women the ovarian vein has been observed to have higher concentrations of testosterone than is found in peripheral blood; bilateral oophorectomy results in reductions in testosterone levels by as much as $50 \%$ [5].

Several smaller cross-sectional studies have found lower testosterone levels in postmenopausal than premenopausal women [6-8] or lower levels in perimenopausal than premenopausal women [2]. Large longitudinal studies that have followed women through the menopausal transition have observed either no significant change in testosterone [2,9] or a $15 \%$ decrease in both testosterone and androstenedione at menopause [10]. In one study of women aged 50-89 years testosterone levels were lowest at the time of the menopause, whereas women older than 70 years or more than 20 years postmenopause had levels approximating those of premenopausal women [11]. 
In summary, there is increasing evidence that the ovary continues to produce androstenedione and testosterone in healthy postmenopausal women. Levels may either remain the same or decrease slightly at menopause. However, women with bilateral oophorectomy may be androgen deficient.

\section{Testosterone and breast cancer risk Prospective studies that examined the association between testosterone and breast cancer}

Data from eight prospective cohort studies have been reported on the association between endogenous testosterone levels and breast cancer risk using testosterone measured from blood samples gathered at baseline from postmenopausal women [12-19]. Six of these studies were nested case-control studies [12,14-18]; one was a case-cohort study [19] and one a full cohort study [13]. Only one of these studies reported results for premenopausal women [12].

Six of the eight studies reported a statistically significant increase in postmenopausal breast cancer risk with increasing levels of endogenous testosterone [14-19]. A recently conducted pooled analysis [20] of these eight prospective studies estimated that the relative risk for breast cancer in women whose levels of testosterone were in the top quintile as compared with women in the bottom quintile was 2.22 (95\% confidence interval 1.59-3.10). A statistically significant dose-response relationship was also observed ( $P$ for trend <0.001) [20]. Two of the studies also reported statistically significantly increasing breast cancer risk with increasing levels of free testosterone $[15,19]$, a measure of bioavailable testosterone.

The study of premenopausal women [12] found no statistically significant differences between cases and noncases in mean levels in either premenopausal or postmenopausal women, but the sample size was small (premenopausal women: 17 cases, 67 controls; postmenopausal women: 22 cases, 88 controls).

\section{Can the observed association between testosterone levels and breast cancer risk be due to bias?}

Effects of measurement biases

One limitation of the studies reviewed is that serum testosterone may not be the ideal measure of testosterone. Total testosterone includes both free testosterone and bound testosterone. Furthermore, serum levels do not take into account the peripheral conversion of precursor androgens into testosterone in the breast tissue itself. The effect of this measurement error is most likely to be nondifferential, therefore biasing results toward the null.

Measurement biases due to use of a single hormone measurement or degradation of hormones in stored specimens over time would most likely be nondifferential, resulting in attenuated estimates of disease risk. All of the existing prospective studies (Table 1) analyzed testosterone measured from only one blood draw, which might not be representative of the cumulative exposure to testosterone; however, given the prospective design of the studies, any inaccuracy in measurement would probably bias risk estimates toward the null.

The consideration of time of day that blood was drawn and fasting status can help to avoid the biases due to using a single hormone measurement. To avoid this bias, three of the studies either matched with respect to time of blood draw $[14,18]$ or restricted individuals to having their blood drawn in the morning [13]. Because the effect of these sporadic variations would be to bias the results toward the null, this may help to explain one of the null associations observed [12].

The studies that observed an association between testosterone and breast cancer risk attempted to reduce measurement bias due to degradation by matching cases to controls on the date of blood draw [14-18] and storage conditions such as sample location/shelf in the freezer [15]. This was not done in the studies reporting no association between testosterone and breast cancer risk [12,13] or in one of the positive studies [19].

Laboratory assay variation would also most likely be nondifferential because cases and controls were analyzed concurrently in these studies. The intra-assay and interassay coefficients of variation in these studies were rather good, ranging from $4 \%$ to $14 \%$. However, the coefficient of variation was not reported in one of the null studies [12].

Thus, although there may be some attenuation in effect estimates in all of the studies, it is not clear whether measurement bias due to degradation can explain the discrepancies between the two null studies and the positive studies.

Temporal Bias

If breast cancer development increases testosterone levels, then studies that included individuals diagnosed shortly after baseline hormone measurement may have artificially elevated estimates of the risk for breast cancer associated with testosterone levels. Two of the positive studies and both of the null studies excluded those who were diagnosed 6-24 months after baseline [12-14,17]. However, the study with the most conservative cut-point of 24 months [14] reported a significant positive association between testosterone levels and breast cancer risk. Thus, although it is possible that temporal bias played a role in the four positive studies with no exclusions, this latter study suggests that temporal bias cannot explain the association between testosterone and breast cancer risk. 


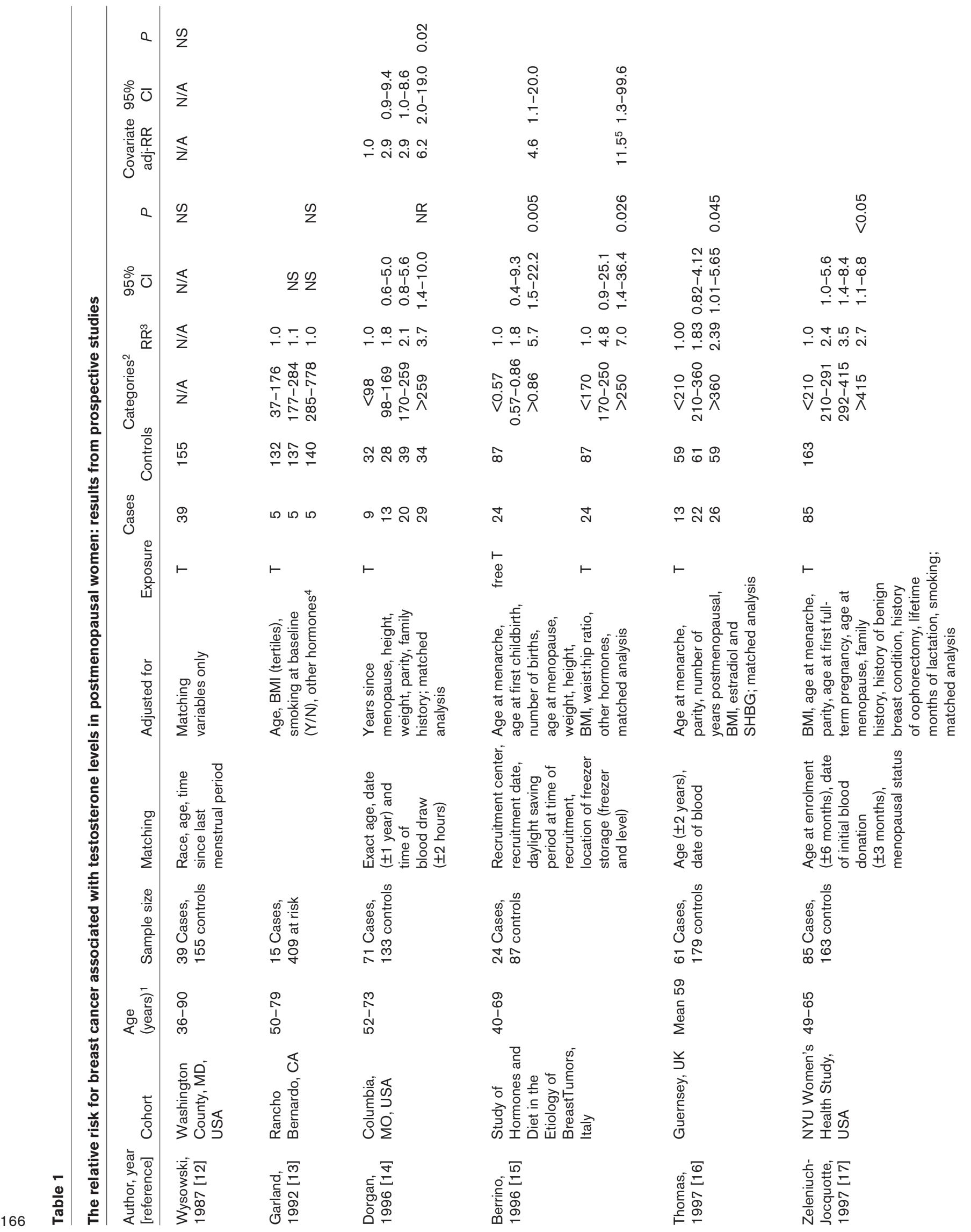




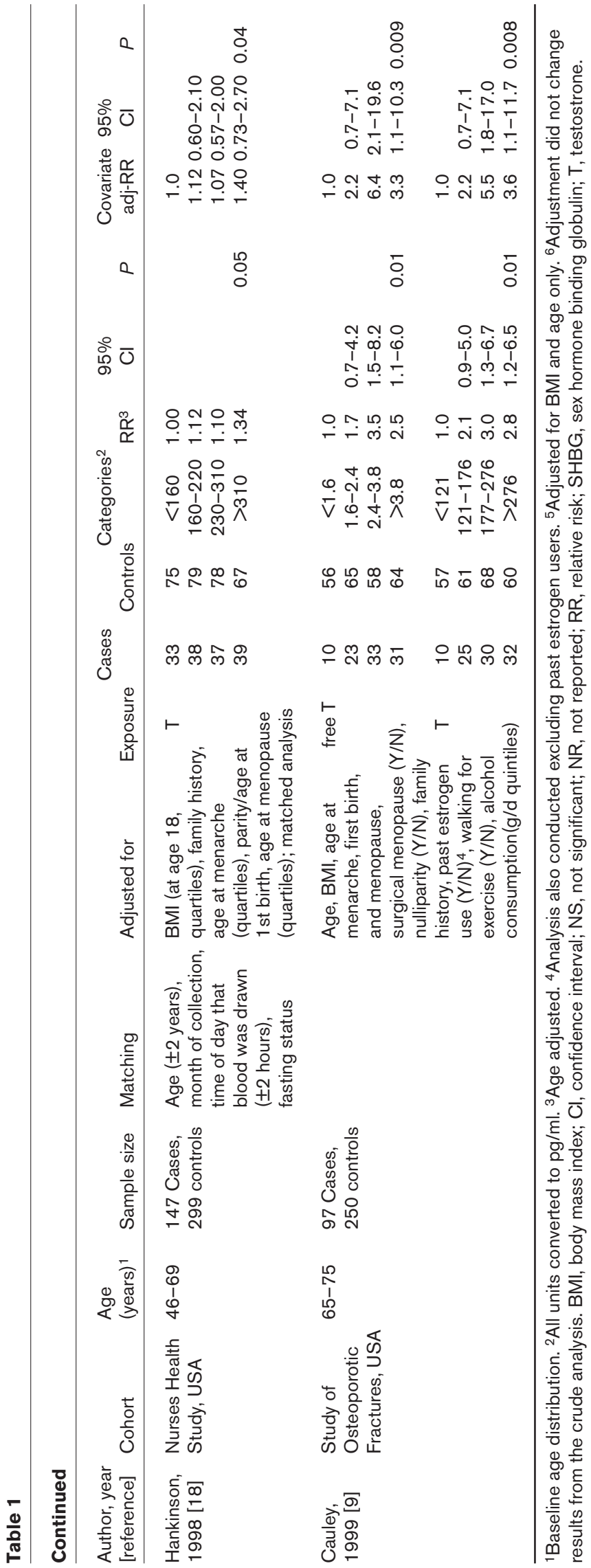

\section{Effects of confounding}

Lack of control for body mass index (BMI) or age at menopause could result in a positive bias away from the null. All of the studies that reported a significant association between testosterone levels and breast cancer risk included either BMI or height and weight as covariates in the statistical model. All but one of the null studies [13] considered either the amount of time menopausal $[12,14,16]$ or age at menopause $[15,17-19]$ as a covariate to control for the effects of menopause on testosterone levels. Thus, it is unlikely that confounding by these variables can explain the associations observed between testosterone levels and breast cancer risk.

\section{Comparability/generalizability}

All of the prospective studies that examined the testosterone-breast cancer association were conducted using cohorts from Caucasian populations. Only two studies $[15,16]$ were conducted outside the USA, one in Italy [15] and one on the island of Guernsey [16]. It is therefore unlikely that differences in the populations studied can explain the discrepant results between studies. There are, as far as we know, no prospective data from nonwhite populations.

\section{Studies of testosterone measured after diagnosis that examined the testosterone-breast cancer association}

Several case-control studies published during the past 20 years have evaluated the association between testosterone levels and breast cancer risk. Comparisons with levels in control individuals have shown that breast cancer patients who were postmenopausal [21-25] and those who were premenopausal [26-28] had significantly elevated testosterone levels. Table 2 presents the odds ratios of breast cancer associated with categories of serum testosterone, whereas Table 3 presents results of studies that compared mean levels of testosterone. The measures of testosterone in cases were almost twice those of controls. Although these retrospective studies support the prospective study results showing an association between increased testosterone and increased breast cancer risk, these results may not be as readily interpretable as those from the prospective studies, given the possibility that the presence of cancer, or the treatment for it, might have increased testosterone levels.

\section{Summary}

Both retrospective and prospective studies have reported statistically significant associations between increased levels of testosterone and increased breast cancer risk. These associations are unlikely to be due to measurement biases, the influence of disease, or lack of adjustment for the confounding effects of BMI or age at menopause. 
Table 2

The relative risk of breast cancer associated with testosterone levels: results from case-control studies

\begin{tabular}{|c|c|c|c|c|c|c|c|c|}
\hline $\begin{array}{l}\text { Author, year } \\
\text { [reference] }\end{array}$ & Population & Exposure & Cases & Controls & Categories $^{1}$ & OR & $95 \% \mathrm{Cl}$ & $P$ \\
\hline \multirow[t]{2}{*}{$\begin{array}{l}\text { Secreto, } \\
1984[27]^{2}\end{array}$} & \multirow[t]{2}{*}{$\begin{array}{l}\text { Premenopausal } \\
\text { women in Milan }\end{array}$} & Serum T & $\begin{array}{r}13 \\
4 \\
10\end{array}$ & $\begin{array}{r}47 \\
9 \\
6\end{array}$ & $\begin{array}{r}<590 \\
590-670 \\
671+\end{array}$ & $\begin{array}{r}1.0 \\
2.6 \\
10.2\end{array}$ & $\begin{array}{l}0.6-10.9 \\
2.6-40.0\end{array}$ & 0.0004 \\
\hline & & Urinary $\mathrm{T}$ & $\begin{array}{r}9 \\
4 \\
10\end{array}$ & $\begin{array}{r}35 \\
7 \\
5\end{array}$ & $\begin{array}{r}<8.2 \\
8.2-10.5 \\
10.6+\end{array}$ & $\begin{array}{l}1.0 \\
2.3 \\
8.4\end{array}$ & $\begin{array}{l}1.2-12.9 \\
2.1-33.6\end{array}$ & 0.002 \\
\hline \multirow[t]{2}{*}{$\begin{array}{l}\text { Secreto, } \\
1989[28]^{2}\end{array}$} & \multirow[t]{2}{*}{$\begin{array}{l}\text { Women in Milan } \\
\text { age } 30-49 \text { years }\end{array}$} & Serum $T$ & $\begin{array}{l}31 \\
32\end{array}$ & $\begin{array}{l}51 \\
17\end{array}$ & $\begin{array}{l}<309 \\
309+\end{array}$ & $\begin{array}{l}1.0 \\
3.4\end{array}$ & $1.6-7.3$ & 0.05 \\
\hline & & Urinary $\mathrm{T}$ & $\begin{array}{l}36 \\
24\end{array}$ & $\begin{array}{l}50 \\
16\end{array}$ & $\begin{array}{l}<7.6 \\
7.6+\end{array}$ & $\begin{array}{l}1.0 \\
2.1\end{array}$ & $0.9-4.8$ & NS \\
\hline \multirow[t]{3}{*}{$\begin{array}{l}\text { Secreto, } \\
1991[24]^{3}\end{array}$} & \multirow[t]{3}{*}{$\begin{array}{l}\text { Postmenopausal } \\
\text { women in Milan } \\
<69 \text { years of age }\end{array}$} & Serum T & $\begin{array}{l}16 \\
16 \\
18 \\
25\end{array}$ & $\begin{array}{l}40 \\
40 \\
38 \\
32\end{array}$ & $\begin{array}{r}<146 \\
146-212 \\
213-275 \\
>275\end{array}$ & $\begin{array}{l}1.0 \\
1.2 \\
1.5 \\
2.7\end{array}$ & $\begin{array}{l}0.5-3.0 \\
0.6-3.7 \\
1.1-6.7\end{array}$ & 0.03 \\
\hline & & Urinary $\mathrm{T}^{4}$ & $\begin{array}{l}11 \\
14 \\
17 \\
30\end{array}$ & $\begin{array}{l}43 \\
38 \\
37 \\
26\end{array}$ & $\begin{array}{r}<18 \\
18-31 \\
32-46 \\
>46\end{array}$ & $\begin{array}{l}1.0 \\
1.2 \\
2.2 \\
4.7\end{array}$ & $\begin{array}{r}0.5-2.9 \\
0.8-5.7 \\
1.8-12.1\end{array}$ & 0.001 \\
\hline & & Serum DHT & $\begin{array}{l}15 \\
20 \\
16 \\
24\end{array}$ & $\begin{array}{l}37 \\
40 \\
38 \\
35\end{array}$ & $\begin{array}{r}<36 \\
36-57 \\
58-82 \\
>82\end{array}$ & $\begin{array}{l}1.0 \\
1.6 \\
1.3 \\
2.0\end{array}$ & $\begin{array}{l}0.7-3.7 \\
0.5-3.1 \\
0.8-5.0\end{array}$ & NS \\
\hline $\begin{array}{l}\text { Lipworth, } \\
1996[25]^{5}\end{array}$ & $\begin{array}{l}\text { Postmenopausal } \\
\text { women from Sweder }\end{array}$ & $\begin{array}{l}\text { Serum } T^{6} \\
n\end{array}$ & $\begin{array}{l}23 \\
15 \\
47 \\
36\end{array}$ & $\begin{array}{l}35 \\
27 \\
30 \\
30\end{array}$ & $\begin{array}{l}260 \\
350 \\
470 \\
700\end{array}$ & $\begin{array}{l}1.00 \\
0.75 \\
2.64 \\
2.30\end{array}$ & $\begin{array}{l}0.33-1.75 \\
1.27-5.46 \\
0.97-5.50\end{array}$ & 0.041 \\
\hline
\end{tabular}

${ }^{1}$ Serum $\mathrm{T}$ and DHT converted to $\mathrm{pg} / \mathrm{ml}$ and urinary T converted to $\mu \mathrm{g} / 24$ hours. ${ }^{2}$ Age adjusted model. ${ }^{3}$ Adjusted for age, occupation and number of children. ${ }^{4}$ Units in $\mathrm{pg} / \mathrm{ml}$. ${ }^{5} \mathrm{Adjusted}$ for age and residence. ${ }^{6}$ Categorized by quartile medians. Cl, confidence interval; DHT, dihydrotestosterone; NS, not significant; OR, odds ratio; T, testosterone.

Table 3

Mean levels of testosterone in breast cancer cases and controls

\begin{tabular}{|c|c|c|c|c|c|c|c|}
\hline $\begin{array}{l}\text { Author, year } \\
\text { [reference] }\end{array}$ & Population & Exposure & Group & $n$ & Mean $^{1}$ & SD & $P^{2}$ \\
\hline $\begin{array}{l}\text { Secreto, } \\
1983 \text { [21] }\end{array}$ & $\begin{array}{l}\text { Postmenopausal } \\
\text { women }\end{array}$ & Serum $\mathrm{T}$ & $\begin{array}{l}\text { Controls } \\
\text { Carcinoma }\end{array}$ & $\begin{array}{l}30 \\
28\end{array}$ & $\begin{array}{l}310 \\
550\end{array}$ & $\begin{array}{l}110 \\
200\end{array}$ & 0.001 \\
\hline $\begin{array}{l}\text { Secreto, } \\
1983 \text { [26] }\end{array}$ & $\begin{array}{l}\text { Premenopausal } \\
\text { women }\end{array}$ & Urinary $\mathrm{T}$ & $\begin{array}{l}\text { Controls } \\
\text { Familiality } \\
\text { Hyperplasia } \\
\text { Carcinoma }\end{array}$ & $\begin{array}{l}22 \\
21 \\
39 \\
18\end{array}$ & $\begin{array}{l}6.25 \\
5.41 \\
6.97 \\
11.3\end{array}$ & $\begin{array}{l}3.48 \\
3.60 \\
4.44 \\
6.78\end{array}$ & $\begin{array}{r}\text { NS } \\
\text { NS } \\
0.01\end{array}$ \\
\hline $\begin{array}{l}\text { Secreto, } \\
1984 \text { [27] }\end{array}$ & $\begin{array}{l}\text { Premenopausal } \\
\text { women }\end{array}$ & Serum T & $\begin{array}{l}\text { Controls } \\
\text { Breast Hyperplasia } \\
\text { Breast Cancer }\end{array}$ & $\begin{array}{l}55 \\
31 \\
23\end{array}$ & $\begin{array}{l}470 \\
550 \\
620\end{array}$ & $\begin{array}{l}160 \\
200 \\
220\end{array}$ & $\begin{array}{r}<0.05 \\
<0.005\end{array}$ \\
\hline $\begin{array}{l}\text { Hill, } \\
1985 \text { [22] }\end{array}$ & $\begin{array}{l}\text { Postmenopausal } \\
\text { women }\end{array}$ & Serum $\mathrm{T}$ & $\begin{array}{l}\text { Healthy Caucasian } \\
\text { Healthy Japanese } \\
\text { Cases Japanese }\end{array}$ & $\begin{array}{l}43 \\
59 \\
33\end{array}$ & $\begin{array}{l}\mathrm{NS} \\
\mathrm{NS} \\
\mathrm{NS}^{3}\end{array}$ & & $\begin{array}{l}0.01 \\
0.01\end{array}$ \\
\hline $\begin{array}{l}\text { Adlercreutz, } \\
1989 \text { [23] }\end{array}$ & $\begin{array}{l}\text { Postmenopausal } \\
\text { women }\end{array}$ & Serum T & $\begin{array}{l}\text { Vegetarians } \\
\text { Omnivores } \\
\text { Cases }\end{array}$ & $\begin{array}{r}10 \\
9 \\
8\end{array}$ & $\begin{array}{l}172.80 \\
233.28 \\
319.68\end{array}$ & $\begin{array}{r}86.40 \\
66.24 \\
132.48\end{array}$ & $\begin{array}{l}<0.05 \\
<0.05\end{array}$ \\
\hline
\end{tabular}

${ }^{1}$ Serum T converted to $\mathrm{pg} / \mathrm{ml}$ and urinary T converted to $\mu \mathrm{g} / 24$ hours. ${ }^{2}$ Comparisons with mean levels in controls using the $t$-test. ${ }^{3} \mathrm{Comparison}$ with healthy Japanese group. SD, standard deviation; T, testosterone. 


\section{Androgen receptor, the AR-CAG repeat, and breast cancer risk}

The main receptor for testosterone is the AR. A functional polymorphism in the $A R$ gene has been examined in female breast cancer, and the literature is reviewed to shed light on the possible mechanisms by which testosterone may affect breast cancer risk.

\section{Androgen receptor protein and breast cancer}

The AR is expressed in the majority of breast cancers [29-35]. Several studies have been conducted to examine the effects of androgens on the growth of AR-positive breast cancer cell lines. These studies have reported both inhibitory $[36,37]$ and stimulatory $[38,39]$ effects. These divergent effects have been observed to be specific to the cell line under study [40].

To our knowledge, the only in vivo study of the effect of testosterone on breast cell proliferation was conducted in rats and showed that treatment with testosterone results in both tumor regression and a reduction in estrogen receptor expression [41]. However, it is unclear whether the testosterone levels used represent physiologic doses. No in vivo or epidemiologic studies have examined the association between serum or tissue testosterone levels and breast cell proliferation in tumors with varying degrees of AR expression.

In summary, the effects of androgens on breast cancer cell growth are still unclear. In contrast to the epidemiologic observation of a consistent association between serum testosterone levels and increasing breast cancer risk, in vivo studies reported an antiproliferative effect and in vitro studies reported both proliferative and antiproliferative effects.

\section{The androgen receptor gene and a polymorphic CAG repeat}

The AR is encoded by a single 90 kilobase gene on the $X$ chromosome (Xq11-q12), which encodes a 11-kilobase mRNA transcript composed of eight exons [42-46]. Epidemiologic evidence for a role of the $A R$ gene in breast cancer was first suggested by studies of male breast cancer patients. A mutation in $A R$ in the DNA-binding domain resulting in an inability to bind androgens was first reported in a pair of brothers with breast cancer [47]. In a study of 13 male breast cancer patients, one was observed to carry a similar mutation [48]. In another small study of 11 male breast cancer patients [49], this mutation was not observed. These results suggested that the mutation may play a role in the development of breast cancer in some males.

Within the first exon of $A R$ lies a polymorphic CAG repeat that encodes a polyglutamine tract of variable length. The normal size range of these repeats is between 6 and 39 repeats [50,51]. Between 40 and 66 repeats have been observed in patients with a rare, neurodegenerative disorder called spinal and bulbar muscular atrophy [52], which is characterized by androgen insensitivity with gynecomastia, testicular atrophy, oligospermia, azoospermia, and elevated serum gonadotropins.

\section{$A R$-CAG repeat length and androgen receptor activity}

Several studies have observed an association between increasing $A R$-CAG repeat length and a linear decrease in AR transactivation activity [53-56]. Consistent with this, male carriers of the short $A R$-CAG repeat length are at increased risk for prostate cancer [51,57-62].

\section{AR-CAG repeat length and breast cancer}

The association between the length of the $A R$-CAG repeat polymorphism and breast cancer risk has been examined in several case-control studies (Table 4) [63-68]. The long AR-CAG repeat, which is representative of the less active AR, was associated with a statistically significant increase in breast cancer risk in a population of women from Quebec [66] and in a population of BRCA1 mutation carriers [63]. Four additional studies $[64,65,67,69]$ reported slightly increased risk for breast cancer associated with the long allele, but none of these findings were statistically significant. A study nested within the Nurses' Health Study cohort [68] found no increased breast cancer risk associated with the long AR allele overall, but an increased risk was observed when analyses were limited to those individuals with a firstdegree family history of breast cancer (odds ratio 1.70, 95\% confidence interval 1.2-2.4). Another trinucleotide repeat in the $A R$, a GGC repeat, has been observed to be associated with prostate cancer risk $[59,60,62,70,71]$. One of three studies that examined the GGC repeat length and breast cancer $[65,67,69]$ found a significant association in women diagnosed before age 45 years [69], but no evidence of an interaction between the CAG and GGC repeat with breast cancer risk was observed.

The three studies that reported a significant association between long AR-CAG repeat and breast cancer risk $[63,66,68]$ included both premenopausal and postmenopausal women. One study stratified with respect to menopausal status and found that the significant association with the long $A R$-CAG repeat was observed only in postmenopausal women (odds ratio 3.22, 95\% confidence interval 1.54-6.75) and not in premenopausal women (odds ratio 1.03, 95\% confidence interval $0.43-2.48$ ). If this effect modification is true then it may explain, at least in part, the nonsignificant results in the studies restricted to women aged under 40 years [64].

\section{Issues with the studies of AR-CAG repeat length and breast cancer risk}

The gene for the $A R$ lies on the $\mathrm{X}$ chromosome, and therefore women carry two alleles whereas men carry only a 


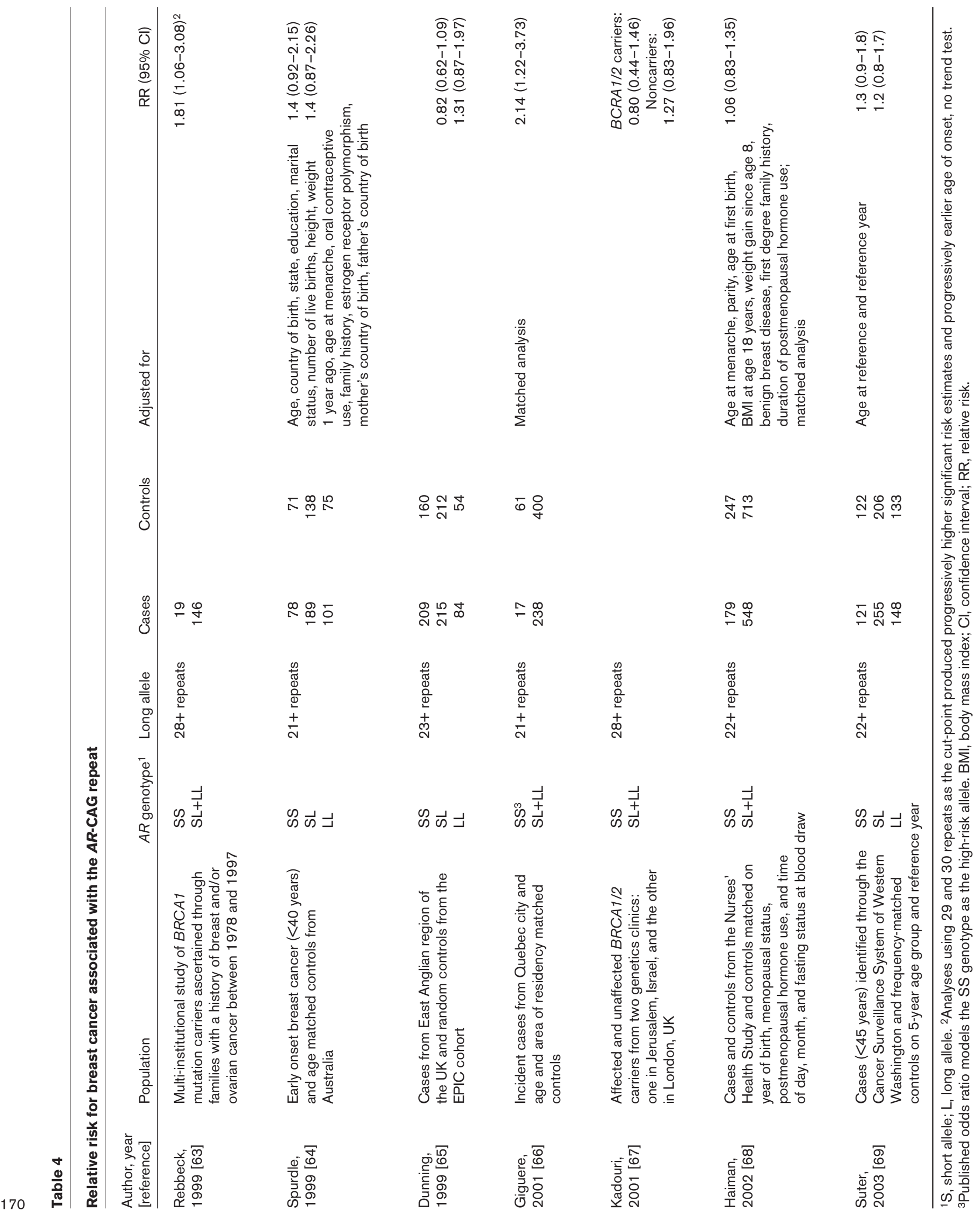


single allele. In general, normal women are a mosaic, with one allele randomly expressed in each cell. A recent study [72] reported that $13 \%$ of young (27-45 years old) breast cancer cases exhibited preferential activation of one of the $A R$ alleles as measured by genotyping of peripheral blood DNA, but there was no preference toward the allele with the longer or shorter CAG repeat. Analyses of the $A R$ in women that only consider the length of the CAG repeat on one allele assume that this is the active allele in the breast tissue. Analyses that use the average of the $\mathrm{CAG}$ repeat lengths or the sum of the repeats consider the contributions of both alleles; however, if only one allele is preferentially expressed then this would result in misclassification. There is a high rate of heterozygosity in the AR-CAG repeat length, and therefore this is likely to be a major misclassification problem, which should bias the results toward the null. Genotyping methods can be optimized to detect better whether there is a preferentially active $A R$ allele by either genotyping tumor tissue or serum DNA using methylation sensitive enzymes [72].

\section{Summary}

The studies conducted thus far suggest that the long $A R$-CAG repeat (less active $\mathrm{AR}$ ) may be associated with increased breast cancer risk in women who are postmenopausal, have a first-degree family history of breast cancer or who have a known BRCA1 mutation. The location of the $A R$ gene on the $\mathrm{X}$ chromosome means that results from epidemiologic studies will be biased toward the null as long as we do not know which allele is expressed.

\section{Discussion}

If the long $A R$-CAG repeat (less active $A R$ ) is associated with increased breast cancer risk in postmenopausal women, then how do these results coincide with results showing that increased testosterone levels increase postmenopausal breast cancer risk?

One hypothesis to explain this apparent paradox is that the less active AR may be involved in a physiologic feedback associated with increased circulating testosterone. However, the only data available discount this hypothesis. Two studies have examined the association between the AR-CAG repeat length and circulating testosterone levels in normal women $[68,73]$. AR-CAG repeat length was inversely associated with testosterone levels. In other words, the less active AR was associated with lower circulating testosterone levels, and the results were statistically significant both in a study of premenopausal women [73] and in a study of postmenopausal women [68].

If the AR is not involved in a feedback mechanism to influence testosterone levels in postmenopausal women, then it is possible that the effect of testosterone on the breast epithelium does not act through binding to the AR. Testosterone may exert its effect on breast tissue through con- version of testosterone to estrone, which is then aromatized into estradiol in adipose tissue, and the increased estradiol levels may result in increased breast cell proliferation and breast cancer risk.

Testosterone may also exert an indirect effect on breast cancer proliferation by sequestering sex hormone binding globulin, leaving more estradiol in the non-protein-bound state and able to act on breast tissue [25,74]. Approximately $66 \%$ of total testosterone is bound to sex hormone binding globulin, $31 \%$ is bound to albumin, and $2 \%$ is bound to cortisol binding protein [75]. Two of the studies suggesting an association between testosterone and breast cancer $[16,17]$ reported that this association disappeared when adjusting for estradiol levels. However, in the pooled analysis [20] the significant association between testosterone and breast cancer risk remained after adjustment for estradiol [20].

Finally, it is possible that further studies will show that $A R$-CAG repeat length is not linked to breast cancer risk.

\section{Conclusion}

Prospectively conducted epidemiologic studies have found that increased levels of serum testosterone are associated with an increase in postmenopausal breast cancer risk. However, a number of questions remain. Several lines of evidence suggest a role of AR in breast cancer risk, and sparse epidemiologic data suggest that a long AR-CAG repeat yielding a less active AR may be associated with increased risk. There still remain a number of questions on how testosterone increases breast cancer risk. Although in vitro studies report both proliferative and antiproliferative effects of testosterone on the growth of various breast cancer cell lines, we still need to further understand under which in vivo circumstances does testosterone exert these effects. Finally, we do not know whether androgens affect breast cancer risk in premenopausal women. Further analyses of the role of $A R$-CAG repeat length and breast cancer using genotyping methods that assess which allele is the active AR allele are clearly needed. Additional data are also needed to help elucidate the apparent paradox between the AR-CAG repeat length, testosterone levels, and breast cancer risk.

\section{Competing interests}

None declared.

\section{Acknowledgements}

This research (EOL) was supported by funds from the California Breast Cancer Research Program, Grant Number 8GB-0010.

\section{References}

1. Norman AW, Litwack G: Hormones. San Diego, CA: Academic Press; 1987.

2. Longcope C, Franz C, Morello C, Baker R, Johnston CC Jr: Steroid and gonadotropin levels in women during the perimenopausal years. Maturitas 1986, 8:189-196. 
3. Abraham GE: Ovarian and adrenal contribution to peripheral androgens during the menstrual cycle. J Clin Endocrinol Metab 1974, 39:340-346.

4. Adashi EY: The climacteric ovary as a functional gonadotropin-driven androgen-producing gland. Fertil Steril 1994, 62:20-27.

5. Judd HL, Lucas WE, Yen SS: Effect of oophorectomy on circulating testosterone and androstenedione levels in patients with endometrial cancer. Am J Obstet Gynecol 1974, 118:793-798.

6. Zumoff B, Strain GW, Miller LK, Rosner W: Twenty-four-hour mean plasma testosterone concentration declines with age in normal premenopausal women. J Clin Endocrinol Metab 1995, 80:1429-1430.

7. Bancroft J, Cawood EH: Androgens and the menopause: a study of 40-60-year-old women. Clin Endocrinol (Oxf) 1996, 45:577-587.

8. Labrie F, Belanger A, Cusan L, Gomez JL, Candas B: Marked decline in serum concentrations of adrenal $\mathrm{C} 19$ sex steroid precursors and conjugated androgen metabolites during aging. J Clin Endocrinol Metab 1997, 82:2396-2402.

9. Burger HG, Dudley EC, Cui J, Dennerstein L, Hopper JL: A prospective longitudinal study of serum testosterone, dehydroepiandrosterone sulfate, and sex hormone-binding globulin levels through the menopause transition. $J$ Clin Endocrinol Metab 2000, 85:2832-2838.

10. Rannevik G, Jeppsson S, Johnell O, Bjerre B, Laurell-Borulf $Y$, Svanberg L: A longitudinal study of the perimenopausal transition: altered profiles of steroid and pituitary hormones, SHBG and bone mineral density. Maturitas 1995, 21:103-113.

11. Laughlin GA, Barrett-Connor E, Kritz-Silverstein D, von Muhlen D: Hysterectomy, oophorectomy, and endogenous sex hormone levels in older women: the Rancho Bernardo Study. J Clin Endocrinol Metab 2000, 85:645-651.

12. Wysowski DK, Comstock GW, Helsing KJ, Lau HL: Sex hormone levels in serum in relation to the development of breast cancer. Am J Epidemiol 1987, 125:791-799.

13. Garland CF, Friedlander NJ, Barrett-Connor E, Khaw KT: Sex hormones and postmenopausal breast cancer: a prospective study in an adult community. Am J Epidemiol 1992, 135:12201230.

14. Dorgan JF, Longcope C, Stephenson HE, Jr., Falk RT, Miller R, Franz C, Kahle L, Campbell WS, Tangrea JA, Schatzkin A: Relation of prediagnostic serum estrogen and androgen levels to breast cancer risk. Cancer Epidemiol Biomarkers Prev 1996, 5:533-539.

15. Berrino F, Muti P, Micheli A, Bolelli G, Krogh V, Sciajno R, Pisani $P$, Panico $S$, Secreto $G$ : Serum sex hormone levels after menopause and subsequent breast cancer. $J$ Natl Cancer Inst 1996, 88:291-296

16. Thomas HV, Key TJ, Allen DS, Moore JW, Dowsett M, Fentiman IS, Wang DY: A prospective study of endogenous serum hormone concentrations and breast cancer risk in postmenopausal women on the island of Guernsey. $\mathrm{Br} J$ Cancer 1997, 76:401-405

17. Zeleniuch-Jacquotte A, Bruning PF, Bonfrer JM, Koenig KL, Shore RE, Kim MY, Pasternack BS, Toniolo P: Relation of serum levels of testosterone and dehydroepiandrosterone sulfate to risk of breast cancer in postmenopausal women. Am J Epidemiol 1997, 145:1030-1038.

18. Hankinson SE, Willett WC, Manson JE, Colditz GA, Hunter DJ, Spiegelman D, Barbieri RL, Speizer FE: Plasma sex steroid hormone levels and risk of breast cancer in postmenopausal women. J Natl Cancer Inst 1998, 90:1292-1299.

19. Cauley JA, Lucas FL, Kuller LH, Stone K, Browner W, Cummings $\mathrm{SR}$ : Elevated serum estradiol and testosterone concentrations are associated with a high risk for breast cancer: study of Osteoporotic Fractures Research Group. Ann Intern Med 1999, 130:270-277.

20. Endogenous sex hormones and breast cancer in postmenopausal women: reanalysis of nine prospective studies. $J$ Natl Cancer Inst 2002, 94: 606-616.

21. Secreto G, Recchione C, Cavalleri A, Miraglia M and Dati V: Circulating levels of testosterone, 17 beta-oestradiol, luteinising hormone and prolactin in postmenopausal breast cancer patients. Br J Cancer 1983, 47: 269-275.

22. Hill $P$, Garbaczewski $L$ and Kasumi F: Plasma testosterone and breast cancer. Eur J Cancer Clin Oncol 1985, 21: 1265-1266.
23. Adlercreutz H, Hamalainen E, Gorbach SL, Goldin BR, Woods MN and Dwyer JT: Diet and plasma androgens in postmenopausal vegetarian and omnivorous women and postmenopausal women with breast cancer. Am J Clin Nutr 1989, 49: 433-442.

24. Secreto G, Recchione C, Ballerini P, Callegari L, Cavalleri A, Attili A, Fariselli G, Moglia D and Del Prato I: Accumulation of active androgens in breast cyst fluids. Eur J Cancer 1991, 27: 44-47.

25. Lipworth L, Adami HO, Trichopoulos D, Carlstrom K and Mantzoros C: Serum steroid hormone levels, sex hormone-binding globulin, and body mass index in the etiology of postmenopausal breast cancer. Epidemiology 1996, 7: 96-100.

26. Secreto G, Fariselli G, Bandieramonte G, Recchione C, Dati V and Di Pietro S: Androgen excretion in women with a family history of breast cancer or with epithelial hyperplasia or cancer of the breast. Eur J Cancer Clin Oncol 1983, 19: 5-10.

27. Secreto G, Recchione C, Fariselli G and Di Pietro S: High testosterone and low progesterone circulating levels in premenopausal patients with hyperplasia and cancer of the breast. Cancer Res 1984, 44: 841-844.

28. Secreto G, Toniolo P, Pisani P, Recchione C, Cavalleri A, Fariselli G, Totis A, Di Pietro $S$ and Berrino F: Androgens and breast cancer in premenopausal women. Cancer Res 1989, 49: 471-476.

29. Bryan RM, Mercer RJ, Bennett RC, Rennie GC, Lie TH and Morgan FJ: Androgen receptors in breast cancer. Cancer 1984, 54: $2436-2440$

30. Lea OA, Kvinnsland $\mathrm{S}$ and Thorsen $\mathrm{T}$ : Improved measurement of androgen receptors in human breast cancer. Cancer Res 1989, 49: 7162-7167.

31. Kuenen-Boumeester V, Van der Kwast $T H$, van Putten WL, Claassen C, van Ooijen B and Henzen-Logmans SC: Immunohistochemical determination of androgen receptors in relation to oestrogen and progesterone receptors in female breast cancer. Int J Cancer 1992, 52: 581-584.

32. Soreide JA, Lea OA, Varhaug JE, Skarstein A and Kvinnsland S: Androgen receptors in operable breast cancer: relation to other steroid hormone receptors, correlations to prognostic factors and predictive value for effect of adjuvant tamoxifen treatment. Eur J Surg Oncol 1992, 18: 112-118.

33. Hall RE, Aspinall JO, Horsfall DJ, Birrell SN, Bentel JM, Sutherland $\mathrm{RL}$ and Tilley WD: Expression of the androgen receptor and an androgen-responsive protein, apolipoprotein $D$, in human breast cancer. Br J Cancer 1996, 74: 1175-1180.

34. Bayer-Garner IB and Smoller B: Androgen receptors: a marker to increase sensitivity for identifying breast cancer in skin metastasis of unknown primary site. Mod Pathol 2000, 13: 119-122.

35. Brys M, Wojcik M, Romanowicz-Makowska $\mathrm{H}$ and Krajewska WM: Androgen receptor status in female breast cancer: RT-PCR and Western blot studies. J Cancer Res Clin Oncol 2002, 128: 85-90.

36. Poulin R, Baker D and Labrie F: Androgens inhibit basal and estrogen-induced cell proliferation in the ZR-75-1 human breast cancer cell line. Breast Cancer Res Treat 1988, 12: 213-225.

37. Ortmann J, Prifti S, Bohlmann MK, Rehberger-Schneider S, Strowitzki $\mathrm{T}$ and Rabe T: Testosterone and $\mathbf{5}$ alpha-dihydrotestosterone inhibit in vitro growth of human breast cancer cell lines. Gynecol Endocrinol 2002, 16: 113-120.

38. Hackenberg R, Hofmann J, Holzel F and Schulz KD: Stimulatory effects of androgen and antiandrogen on the in vitro proliferation of human mammary carcinoma cells. J Cancer Res Clin Oncol 1988, 114: 593-601.

39. Marugo M, Bernasconi D, Miglietta L, Fazzuoli L, Ravera F, Cassulo $S$ and Giordano G: Effects of dihydrotestosterone and hydroxyflutamide on androgen receptors in cultured human breast cancer cells (EVSA-T). J Steroid Biochem Mol Biol 1992, 42: 547-554.

40. Birrell SN, Bentel JM, Hickey TE, Ricciardelli C, Weger MA, Horsfall DJ and Tilley WD: Androgens induce divergent proliferative responses in human breast cancer cell lines. J Steroid Biochem Mol Biol 1995, 52: 459-467.

41. Zava DT, McGuire WL: Estrogen receptors in androgen-induced breast tumor regression. Cancer Res 1977, 37: 1608-1610.

42. Chang CS, Kokontis J and Liao ST: Structural analysis of complementary DNA and amino acid sequences of human and rat androgen receptors. Proc Natl Acad Sci U S A 1988, 85: 72117215. 
43. Lubahn DB, Joseph DR, Sullivan PM, Willard HF, French FS and Wilson EM: Cloning of human androgen receptor complementary DNA and localization to the $\mathrm{X}$ chromosome. Science 1988, 240: 327-330.

44. Lubahn DB, Brown TR, Simental JA, Higgs HN, Migeon CJ, Wilson EM and French FS: Sequence of the intron/exon junctions of the coding region of the human androgen receptor gene and identification of a point mutation in a family with complete androgen insensitivity. Proc Natl Acad Sci U $S A$ 1989, 86: 9534-9538.

45. Tilley WD, Marcelli M, Wilson JD and McPhaul MJ: Characterization and expression of a cDNA encoding the human androgen receptor. Proc Natl Acad Sci U S A 1989, 86: 327-331.

46. Brown CJ, Goss SJ, Lubahn DB, Joseph DR, Wilson EM, French FS and Willard HF: Androgen receptor locus on the human $X$ chromosome: regional localization to $\mathrm{Xq11-12}$ and description of a DNA polymorphism. Am J Hum Genet 1989, 44: 264269.

47. Wooster R, Mangion J, Eeles R, Smith S, Dowsett M, Averill D, Barrett-Lee P, Easton DF, Ponder BA and Stratton MR: A germline mutation in the androgen receptor gene in two brothers with breast cancer and Reifenstein syndrome. Nat Genet 1992, 2: 132-134.

48. Lobaccaro JM, Lumbroso S, Belon C, Galtier-Dereure F, Bringer J, Lesimple T, Heron JF, Pujol $\mathrm{H}$ and Sultan C: Male breast cancer and the androgen receptor gene. Nat Genet 1993, 5: 109-110.

49. Hiort O, Naber SP, Lehners A, Muletta-Feurer S, Sinnecker GH, Zollner $\mathrm{A}$ and Komminoth $\mathrm{P}$ : The role of androgen receptor gene mutations in male breast carcinoma. J Clin Endocrinol Metab 1996, 81: 3404-3407.

50. Edwards A, Hammond HA, Jin L, Caskey CT and Chakraborty R: Genetic variation at five trimeric and tetrameric tandem repeat loci in four human population groups. Genomics 1992, 12: 241-253

51. Giovannucci E, Stampfer MJ, Krithivas K, Brown M, Dahl D, Brufsky A, Talcott J, Hennekens CH and Kantoff PW: The CAG repeat within the androgen receptor gene and its relationship to prostate cancer. Proc Natl Acad Sci U S A 1997, 94: 33203323.

52. La Spada AR, Wilson EM, Lubahn DB, Harding AE and Fischbeck $\mathrm{KH}$ : Androgen receptor gene mutations in X-linked spinal and bulbar muscular atrophy. Nature 1991, 352: 77-79.

53. Chamberlain NL, Driver ED and Miesfeld RL: The length and location of CAG trinucleotide repeats in the androgen receptor $\mathrm{N}$-terminal domain affect transactivation function. Nucleic Acids Res 1994, 22: 3181-3186.

54. Kazemi-Esfariani $P$, Trifiro MA and Pinsky L: Evidence for a repressive function of the long polyglutamine tract in the human androgen receptor: possible pathogenetic relevance for the (CAG)n-expanded neuronopathies. Hum Mol Genet 1995, 4: 523-527.

55. Tut TG, Ghadessy FJ, Trifiro MA, Pinsky L and Yong EL: Long polyglutamine tracts in the androgen receptor are associated with reduced trans-activation, impaired sperm production, and male infertility. J Clin Endocrinol Metab 1997, 82: 37773782.

56. Irvine RA, Ma H, Yu MC, Ross RK, Stallcup MR and Coetzee GA: Inhibition of p160-mediated coactivation with increasing androgen receptor polyglutamine length. Hum Mol Genet 2000, 9: 267-274

57. Irvine RA, Yu MC, Ross RK and Coetzee GA: The CAG and GGC microsatellites of the androgen receptor gene are in linkage disequilibrium in men with prostate cancer. Cancer Res 1995, 55: $1937-1940$.

58. Ingles SA, Ross RK, Yu MC, Irvine RA, La Pera G, Haile RW and Coetzee GA: Association of prostate cancer risk with genetic polymorphisms in vitamin $\mathrm{D}$ receptor and androgen receptor. J Natl Cancer Inst 1997, 89: 166-170.

59. Stanford JL, Just JJ, Gibbs M, Wicklund KG, Neal CL, Blumenstein BA and Ostrander EA: Polymorphic repeats in the androgen receptor gene: molecular markers of prostate cancer risk. Cancer Res 1997, 57: 1194-1198.

60. Hakimi JM, Schoenberg MP, Rondinelli RH, Piantadosi S and Barrack ER: Androgen receptor variants with short glutamine or glycine repeats may identify unique subpopulations of men with prostate cancer. Clin Cancer Res 1997, 3: 15991608.
61. Ekman $\mathrm{P}$, Gronberg $\mathrm{H}$, Matsuyama $\mathrm{H}$, Kivineva $\mathrm{M}$, Bergerheim US and $\mathrm{Li} \mathrm{C}$ : Links between genetic and environmental factors and prostate cancer risk. Prostate 1999, 39: 262-268.

62. Hsing AW, Gao YT, Wu G, Wang X, Deng J, Chen YL, Sesterhenn IA, Mostofi FK, Benichou J and Chang C: Polymorphic CAG and GGN repeat lengths in the androgen receptor gene and prostate cancer risk: a population-based case-control study in China. Cancer Res 2000, 60: 5111-5116.

63. Rebbeck TR, Kantoff PW, Krithivas K, Neuhausen S, Blackwood MA, Godwin AK, Daly MB, Narod SA, Garber JE, Lynch HT, Weber BL and Brown M: Modification of BRCA1-associated breast cancer risk by the polymorphic androgen-receptor CAG repeat. Am J Hum Genet 1999, 64: 1371-1377.

64. Spurdle AB, Dite GS, Chen X, Mayne CJ, Southey MC, Batten LE Chy H, Trute L, McCredie MR, Giles GG, Armes J, Venter DJ, Hopper JL and Chenevix-Trench G: Androgen receptor exon 1 CAG repeat length and breast cancer in women before age forty years. J Natl Cancer Inst 1999, 91: 961-966.

65. Dunning AM, McBride S, Gregory J, Durocher F, Foster NA, Healey CS, Smith N, Pharoah PD, Luben RN, Easton DF and Ponder BA: No association between androgen or vitamin D receptor gene polymorphisms and risk of breast cancer. Carcinogenesis 1999, 20: 2131-2135.

66. Giguere Y, Dewailly E, Brisson J, Ayotte P, Laflamme N, Demers A, Forest VI, Dodin S, Robert J and Rousseau F: Short polyglutamine tracts in the androgen receptor are protective against breast cancer in the general population. Cancer Res 2001, 61: 5869-5874.

67. Kadouri L, Easton DF, Edwards S, Hubert A, Kote-Jarai Z, Glaser $B$, Durocher F, Abeliovich D, Peretz T and Eeles RA: CAG and GGC repeat polymorphisms in the androgen receptor gene and breast cancer susceptibility in BRCA1/2 carriers and noncarriers. Br J Cancer 2001, 85: 36-40.

68. Haiman CA, Brown M, Hankinson SE, Spiegelman D, Colditz GA, Willett WC, Kantoff PW and Hunter DJ: The androgen receptor CAG repeat polymorphism and risk of breast cancer in the Nurses' Health Study. Cancer Res 2002, 62: 1045-1049.

69. Suter NM, Malone KE, Daling JR, Doody DR and Ostrander EA: Androgen receptor (CAG) and (GGC) polymorphism and breast cancer risk in a population-based case-control study of young women. Cancer Epidemiol Biomarkers Prev 2003, 12: 127-135.

70. Platz EA, Giovannucci E, Dahl DM, Krithivas K, Hennekens $\mathrm{CH}$, Brown M, Stampfer MJ and Kantoff PW: The androgen receptor gene GGN microsatellite and prostate cancer risk. Cancer Epidemiol Biomarkers Prev 1998, 7: 379-384.

71. Chang BL, Zheng SL, Hawkins GA, Isaacs SD, Wiley KE, Turner A, Carpten JD, Bleecker ER, Walsh PC, Trent JM, Meyers DA, Isaacs WB and Xu J: Polymorphic GGC repeats in the androgen receptor gene are associated with hereditary and sporadic prostate cancer risk. Hum Genet 2002, 110: 122-129.

72. Kristiansen M, Langerod A, Knudsen GP, Weber BL, BorresenDale $A L$ and Orstavik $\mathrm{KH}$ : High frequency of skewed $\mathbf{X}$ inactivation in young breast cancer patients. $J$ Med Genet 2002, 39: 30-33.

73. Westberg L, Baghaei F, Rosmond R, Hellstrand M, Landen M, Jansson M, Holm G, Bjorntorp P and Eriksson E: Polymorphisms of the androgen receptor gene and the estrogen receptor beta gene are associated with androgen levels in women. $J$ Clin Endocrinol Metab 2001, 86: 2562-2568.

74. Siiteri PK, Hammond GL and Nisker JA: Increased availability of serum estrogens in breast cancer: a new hypothesis. In Hormones and Breast Cancer. Edited by Pike MC, Siiteri PK and Welsch CW. New York: Cold Spring Harbor Laboratory; 1981: 87-106.

75. Dunn JF, Nisula BC and Rodbard D: Transport of steroid hormones: binding of 21 endogenous steroids to both testosterone-binding globulin and corticosteroid-binding globulin in human plasma. J Clin Endocrinol Metab 1981, 53: 58-68.

\section{Correspondence}

Elizabeth O Lillie, MS, Department of Preventive Medicine, Keck School of Medicine, University of Southern California, 1441 Eastlake Avenue, Nor 4407, Los Angeles, CA 90089-9175, USA. Tel: +1 323 865 0424; fax: +1 3238650142 ; e-mail: osth@usc.edu. 